\title{
Nutritional status, quality of life and life habits of women with irritable bowel syndrome: a case-control study
}

\author{
Ana Paula Monteiro de MENDONÇA ${ }^{1}$, Luciana Miyuki YAMASHITA ${ }^{1}$, Esther Dantas SILVA ${ }^{1}$, Isabela SOLAR ${ }^{1}$, \\ Larissa Ariel Oliveira SANTOS ${ }^{1}$ and Ana Carolina Junqueira VASQUES ${ }^{1,2}$
}

Received: 22 August 2019

Accepted: 17 January 2020

\begin{abstract}
Background - Irritable bowel syndrome is a functional and chronic gastrointestinal disorder that may cause abdominal pain and altered bowel habits, affecting the nutritional status and quality of life of its carriers. Its prevalence is high, affecting about $10 \%$ to $15 \%$ of the general population in developed countries, being more prevalent in women than in men in the proportion 2:1. Objective - The aim of our study was to compare the profile of body adiposity, life habits, and the quality of life of women with irritable bowel syndrome with a healthy control group. Methods - Case-control study on 70 women, 34 with irritable bowel syndrome and 36 healthy. We applied the "Irritable Bowel Syndrome Quality of Life Questionnaire" to assess quality of life. Body adiposity was assessed from body mass index, waist circumference, and waist-to-hip ratio. We investigated the self-reporting of gastrointestinal symptoms with food deemed as problematic for carriers of irritable bowel syndrome and the presence of typical comorbidities. Assessment of life habits included: practice of physical activities, alcoholism, smoking, daytime sleepiness, and exclusion of foods from the feeding routine. For statistical analysis we used the IBM SPSS program, with a significance level at $5 \%$. Results - There was higher volume of central and general adiposity in the case group compared with the control group $(P<0.05)$. Cases presented a higher chance of developing IBS-related comorbidities $(P<0.05)$. About of $80 \%$ of patients with irritable bowel syndrome have excluded some food from the diet $(P<0.01)$ and the total amount of troublesome foods varied from 7 to $21(P<0.01)$. The case group featured worse quality of life compared with the control $(P<0.05)$. Conclusion - Compared to the control group, women with irritable bowel syndrome showed greater body adiposity, higher frequency of comorbidities, greater restriction on the consumption of problematic foods and worse quality of life.
\end{abstract}

HEADINGS - Irritable bowel syndrome. Adiposity. Life style. Quality of life.

\section{INTRODUCTION}

Irritable bowel syndrome (IBS) is a functional, chronic, and often disabling gastrointestinal disorder, characterized by change in bowel habits including diarrhea, constipation, pain and/or discomfort, flatulence and distension ${ }^{(1,2)}$. Its prevalence is high, affecting about $10 \%$ to $15 \%$ of the general population in developed countries, being more prevalent in women than in men in the proportion $2: 1^{(2,3)}$.

In Western countries, IBS is associated with worse quality of life (QOL), economic impact on work absenteeism, and productivity lost, resulting in an average annual spending of billions of dollars on medical assistance ${ }^{(1,2)}$. Patients with IBS feature significant impact on health-related QOL, particularly concerning energy/fatigue, functional limitations due to physical health problems, bodily pain, and overall perception of health ${ }^{(4)}$. Both gastrointestinal symptoms and psychiatric comorbidities (anxiety and depression) independently contribute to the decreased QOL of these patients ${ }^{(5)}$. The patients' fear of gastrointestinal symptoms having adverse consequences is also a predictive of impaired QOL and increased distress ${ }^{(6)}$.
Obesity is a possible comorbidity of IBS, since intestinal motility, subclinical inflammation, diet, and gut microbiota may be interrelated ${ }^{(7,8)}$. Over the last decade, some studies aimed to find associations between body adiposity, gastrointestinal symptoms, and IBS ${ }^{(9-17)}$. Nagasako et al. ${ }^{(9)}$ identified high frequencies of excess weight in patients with IBS. For bariatric patients with IBS, an improvement of IBS symptoms was demonstrated with weight reduction after the bariatric surgery intervention ${ }^{(13)}$. Authors of a recent study on morbid-obesity patients submitted to moderate caloric restriction identified improve in gastrointestinal symptoms of IBS after weight $\operatorname{loss}^{(14)}$. However, other studies did not find higher risk of IBS in obese subjects and this association is still inconclusive ${ }^{(15-18)}$.

In addition, the consumption of some foods can exacerbate gastrointestinal symptoms of IBS. Main foods regarded as troublesome are sources of carbohydrates that are highly fermentable and of low absorption in the intestine, which include fructose in excess of glucose, lactose, oligosaccharides, and polyols, the so-called FODMAPs acronym ${ }^{(19,20)}$. Other troublesome foods for IBS carriers may be spicy foods, greasy foods, sources of biogenic

Declared conflict of interest of all authors: none

Disclosure of funding: Financial support from the National Council for Scientific and Technological Development (CNPq) and São Paulo Research Foundation - FAPESP process no. 15/24918-2 and 15/24920-7.

1 Universidade de Campinas (UNICAMP), Faculdade de Ciências Aplicadas, Campinas, SP, Brasil. 2 Universidade de Campinas (UNICAMP), Gastrocentro, Laboratório de Investigação em Metabolismo e Diabetes (LIMED), Campinas, SP, Brasil.

Corresponding author: Ana Paula Monteiro de Mendonça. E-mail: ana.pmdm@hotmail.com 
amines, lectins, and preservatives as well as foods that can trigger the endogenous secretion of histamine ${ }^{(21)}$. However, the self-reported frequencies for each of these groups in IBS is not well understood.

Few authors have investigated the role of life habits in the development and symptoms of IBS. In a case-control study, the pattern of alcoholic beverages consumption did not differ between patients with IBS and those from the healthy control group, and mild and moderate drinking were poorly associated with gastrointestinal symptoms ${ }^{(22)}$. On the other hand, the excessive consumption of alcoholic beverages been strongly associated with gastrointestinal symptoms in patients with IBS when compared with controls ${ }^{(22)}$. Regarding the use of tobacco, in a recent systematic review carried out by Sirri et al. ${ }^{(23)}$, the authors could not state a significant statistical association with IBS. Different impairments among studies and the lack of prospective studies hindered the generalization and comparability between them ${ }^{(23)}$. Regarding sleep and physical exercise, was demonstrated that sedentary individuals are 3.5 times more likely to suffer from IBS symptoms than those who were physically active ${ }^{(24)}$; in parallel, those with good quality of sleep were 0.13 times less likely to be affected with IBS symptoms than those with sleep impairment ${ }^{(24)}$.

Due to the great challenge that IBS became to health professionals and the remaining gaps in relation to its clinical-behavioral handling, our objective was to investigate associations between quality of life, body adiposity, self-reporting of gastrointestinal symptoms concerning troublesome foods, and life habits of patients with IBS, compared with a group of healthy individuals.

\section{METHODS}

\section{Ethical considerations}

Our study was approved by the Research Ethics Committee of the University of Campinas (protocol no. CAAE 64341316.0.0000.5404). An Informed Consent Form was individually presented and read to all research volunteers. All evaluations were carried out only upon the volunteers' acceptance and signature.

We have acquired the informed consent after indicate all possible physical and psychological damages on subjects and/or their guardians before the experiment is conducted, in accordance with the Declaration of Helsinki.

\section{Study design and casuistry}

Case-control study design, with two convenience samples, being one sample composed of 34 women with IBS, namely the case group, and other sample with 36 healthy women, namely the control group. It was evaluated women aging between 20 and 59 years. Such sample was chosen because of the greater prevalence of IBS in women compared with men ${ }^{(25)}$.

The case group was composed of patients with IBS who have been selected from the Specialized Outpatient Clinic (Ambulatório Médico de Especialidades - AME) of Limeira, in the state of São Paulo, Brazil; and from the Gastroenterology Outpatient Clinic (Ambulatório de Gastroenterologia) of Hospital de Clínicas - UNICAMP, located in the city of Campinas, state of São Paulo, Brazil.

The control group was composed of individuals from the community of the cities of Limeira and Campinas - São Paulo, Brazil. Healthy volunteers were evaluated in the Laboratory of Nutritional Assessment (LANUT) of the School of Applied Sciences - UNICAMP, and in the Laboratory of Investigation on Metabolism and Diabetes (LIMED), located on the campus of University of Campinas.
Inclusion criteria for the control group were women, aged between 18 and 59 years, stable weight over the last six months (change of up to $5 \%$ in body weight), body mass index (BMI) $<30 \mathrm{~kg} / \mathrm{m}^{2}$, without changes in diet for the last six months. Exclusion criteria for the control group were: pregnancy, patients with other diseases that affect the nutritional status and dietary intake (diabetes, dyslipidemias, cancer, AIDS, diseases of the gastrointestinal tract such as intestinal malformation, short bowel syndrome, irritable bowel syndrome, celiac disease, lactose intolerance, inflammatory bowel disease, and Crohn's disease), and neurological disorders affecting cognition and ability to answer the questions.

Inclusion criteria for the case group were women, aging between 18 and 59 years, confirmed diagnosis of IBS according to the ROME III criteria, and not being under nutritional monitoring. Exclusion criteria for the case group were pregnancy, diseases that affect the nutritional status, and dietary intake, and neurological status.

\section{Anamnesis}

It was collected information on personal medical history and family history concerning gastrointestinal-related diseases such as fibromyalgia, chronic fatigue syndrome, temporomandibular joint dysfunctions, chronic pelvic pain, ulcer dyspepsia, and use of laxatives and antidiarrheal medications.

\section{Life habits}

The level of physical activity was assessed by the International Physical Activity Questionnaire (IPAQ) ${ }^{(26)}$. We applied a questionnaire on smoking, which has been classified as follows: smoker (smoked $\geq 100$ cigarettes during life and currently smokes), former smoker (smoked $\geq 100$ cigarettes and no longer smokes), and nonsmoker (smoked $<100$ cigarettes the whole life) ${ }^{(27)}$. The consumption of alcoholic beverages was assessed in drinks as follows: less than 1 drink per month; 1 to 4 drinks per month; 5 to 7 drinks per month; and more than seven drinks per month ${ }^{(27)}$. Sleep was assessed based on the Epworth Sleepiness Scale, translated and validated to the Portuguese version $^{(28)}$. We also questioned participants as for the presence of gastrointestinal symptoms in 42 foods deemed troublesome for IBS carriers ${ }^{(29)}$.

\section{Evaluation of quality of life}

The "Irritable Bowel Syndrome Quality of Life Questionnaire" (IBS-QOL) was applied to evaluate quality of life using the translated version into Portuguese language. The IBS-QOL is an instrument composed of 34 items developed and validated for measuring health-related quality of life of patients with IBS. Its assessment comprises eight domains: dysphoria, interference with activity, body image, health concerns, food prevention, social reaction, sexuality, and relationships. The score of responses ranges from 1 to 5, resulting in an overall score of QOL and in each domain. Values close to 100 represent a better quality of life, while results close to 0 are related to the worst quality of life of patients with $\operatorname{IBS}^{(30)}$.

\section{Anthropometric assessment}

Evaluation of weight occurred using a weighting scale (Welmy ${ }^{\circledR}$ W200) of 200-kg maximum capacity. Volunteers were standing, barefoot, with arms extended to the side of their bodies, and wearing light clothes for a proper measurement. Height was measured by a wall mount stadiometer. Body mass index was calculated and classified according to the criteria of the World Health Organization ${ }^{(31)}$. 
For measurement of waist circumference, patients were standing naked at the site of measurement, which occurred at the umbilical level. It was used a non-extensible measuring tape, and the reading was performed at the end of expiration. For the hip circumference, tape circled hip in the region of greater perimeter between the waist and the thigh ${ }^{(32)}$. We calculated the waist-to-hip ratio.

\section{Statistical analysis}

For statistical analysis we used the IBM SPSS program version 21.0. Average and standard deviation were used for describing parametric data, whereas medians and interquartile range were used for describing nonparametric data. Categorical data were presented in percentage values. We used the Kolmogorov-Smirnov test to evaluate the normality of the distribution of the studied variables. We used Student's $t$-test and Mann-Whitney test for comparing the two independent groups according to the normality of variables. Chi-square test was used to investigate the presence of associations between categorical variables. We calculated odds ratio for presence of diseases between cases and controls. The adopted significance level as a basis for decision was less than $5 \%(P<0.05)$.

\section{RESULTS}

\section{Age and body adiposity}

In TABLE 1 we can observe that the average age in both groups are within the same age group - middle-aged adults. There was significant difference in waist circumference $(P=0.043)$ and hip circumference $(P=0.043)$, evidencing greater metabolic diseases risk in the case group compared with the control group. However, when analyzing waist-to-hip ratio, there was no significant difference $(P=0.423)$ between the groups. Since waist circumference and hip circumference are proportionately higher in the case group, there was no significant statistical difference for waist-to-hip ratio compared with controls. When analyzing BMI $(P=0.005)$, we can observe overweight in the case group while in the control group we observe eutrophy.

TABLE 1. Comparison of age and profile of body adiposity for controls and cases.

\begin{tabular}{|c|c|c|c|}
\hline \multirow{2}{*}{ Variables } & \multicolumn{2}{|c|}{ Research group } & \multirow{2}{*}{$P$ value } \\
\hline & Controls & Cases & \\
\hline Age (years) & $40 \pm 9$ & $46 \pm 12$ & $0.026^{a}$ \\
\hline IBS diagnosis time (years) & - & $6 \pm 5$ & - \\
\hline BMI $\left(\mathrm{kg} / \mathrm{m}^{2}\right)$ & $24.7 \pm 2.8$ & $28.4 \pm 6.7$ & $0.005^{a}$ \\
\hline Waist circumference $(\mathrm{cm})$ & $85.4 \pm 8.7$ & $92.1 \pm 16.6$ & $0.043^{\mathrm{a}}$ \\
\hline Hip circumference $(\mathrm{cm})$ & $100.9 \pm 9.4$ & $106.1 \pm 11.5$ & $0.043^{\mathrm{a}}$ \\
\hline Waist-to-hip ratio & $0.84 \pm 0.07$ & $0.86 \pm 0.1$ & $0.423^{\mathrm{a}}$ \\
\hline
\end{tabular}

Values are presented as mean \pm SD (range). aStudent's $t$-test. IBS: irritable bowel syndrome; BMI: body mass index

\section{Associated comorbidities and use of medicines}

The case group showed the highest frequency of comorbidities associated with IBS when compared with the control group; $P<0.05$ (TABLE 2). In the odds ratio analysis it was identified greater chance for the development of these diseases in the case group compared with the control group. There was no significant difference in the frequency of ulcer dyspepsia $(P=0.47)$ and use of laxatives among groups $(P=0.06)$. Nevertheless, the cases presented a higher use of antidiarrheals compared with the control group $(P=0.008)$.
TABLE 2. Frequency of presence of self-reported diseases and use of medicines for controls and cases.

\begin{tabular}{|c|c|c|c|c|}
\hline \multirow[b]{2}{*}{ Variables } & \multicolumn{2}{|c|}{ Research group } & \multirow{2}{*}{$\begin{array}{c}P \\
\text { value }\end{array}$} & \multirow[b]{2}{*}{ Odds ratio } \\
\hline & $\begin{array}{c}\text { Controls } \\
\mathrm{n}(\%)\end{array}$ & $\begin{array}{l}\text { Cases } \\
\mathrm{n}(\%)\end{array}$ & & \\
\hline Fibromyalgia & $1(2.8)$ & $13(38.2)$ & $0.001^{\mathrm{a}}$ & $21.6(2.6-177.7)$ \\
\hline $\begin{array}{l}\text { Chronic fatigue } \\
\text { syndrome }\end{array}$ & $1(2.8)$ & $13(38.2)$ & $0.001^{\mathrm{a}}$ & $21.6(2.6-177.7)$ \\
\hline $\begin{array}{l}\text { Temporomandibular } \\
\text { joint dysfunctions }\end{array}$ & $5(13.9)$ & $19(55.9)$ & $0.001^{\mathrm{a}}$ & $7.8(2.4-25.1)$ \\
\hline Chronic pelvic pain & $2(5.6)$ & $20(58.8)$ & $0.001^{\mathrm{a}}$ & $24.2(4.9-118.0)$ \\
\hline Ulcer dyspepsia & $0(0.0)$ & $2(5.9)$ & $0.140^{\mathrm{a}}$ & $0.5(0.4-0.6)$ \\
\hline Use of laxatives & $2(5.6)$ & $7(20.6)$ & $0.060^{\mathrm{a}}$ & $4.4(0.8-22.9)$ \\
\hline Use of antidiarrheals & $0(0.0)$ & $6(17.6)$ & $0.008^{\mathrm{a}}$ & $0.4(0.3-0.6)$ \\
\hline
\end{tabular}

Values are presented as $\mathrm{n}(\%)$ or odds ratio (range). ${ }^{\mathrm{a}} \mathrm{Chi}$-square test.

\section{Life habits}

Variables related to life habits are presented in TABLE 3. There was no statistically significant association between smoking $(P=0.189)$, daytime sleepiness $(P=0.314)$ and physical activity $(P=0.82)$ with IBS. The frequency of the consumption of alcoholic beverages was lower in cases compared with controls $(P=0.011)$.

TABLE 3. Comparison of smoking, consumption of alcoholic beverages, sleepiness scale, and physical activity for controls and cases.

\begin{tabular}{|c|c|c|c|c|}
\hline \multirow[b]{2}{*}{ Variables } & & \multicolumn{2}{|c|}{ Research group } & \multirow{2}{*}{$\begin{array}{c}P \\
\text { value }\end{array}$} \\
\hline & & $\begin{array}{l}\text { Controls } \\
\mathrm{n}(\%)\end{array}$ & $\begin{array}{l}\text { Cases } \\
\mathrm{n}(\%)\end{array}$ & \\
\hline \multirow{3}{*}{ Smoking } & Non-smoker & $31(86.9)$ & $27(79.4)$ & \multirow{3}{*}{$0.189^{\mathrm{a}}$} \\
\hline & Former smoker & $5(13.9)$ & $4(11.8)$ & \\
\hline & Smoker & $0(0.0)$ & $3(8.8)$ & \\
\hline \multirow{4}{*}{$\begin{array}{l}\text { Consumption } \\
\text { of alcoholic } \\
\text { beverages }\end{array}$} & $<1$ drink per month & $17(47.2)$ & $28(82.4)$ & \multirow{4}{*}{$0.011^{\mathrm{a}}$} \\
\hline & $\begin{array}{c}1 \text { to } 4 \text { drinks per } \\
\text { month }\end{array}$ & $13(36.1)$ & $5(14.7)$ & \\
\hline & $\begin{array}{c}5 \text { to } 7 \text { drinks per } \\
\text { month }\end{array}$ & $5(13.9)$ & $0(0.0)$ & \\
\hline & $>7$ drinks per month & $1(2.8)$ & $1(2.9)$ & \\
\hline $\begin{array}{l}\text { Daytime } \\
\text { sleepiness }\end{array}$ & & $6 \pm 5$ & $7 \pm 5$ & $0.314^{\mathrm{b}}$ \\
\hline \multirow{3}{*}{$\begin{array}{l}\text { Physical } \\
\text { activity }\end{array}$} & Low & $2(5.6)$ & $0(0.0)$ & \multirow{3}{*}{$0.820^{\mathrm{a}}$} \\
\hline & Moderate & $34(94.4)$ & $34(100.0)$ & \\
\hline & High & $0(0.0)$ & $0(0.0)$ & \\
\hline
\end{tabular}

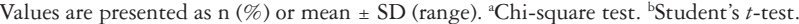

\section{Troublesome foods}

In TABLE 4 we show the frequency of self-reporting of 42 foods deemed troublesome causing gastrointestinal aggravations in case and control groups. Thirty-three $(78.5 \%)$ foods mentioned presented more reports of worsening regarding gastrointestinal symptoms for IBS patients compared with controls $(P<0.05)$. There was significant difference in the average of total amount of troublesome foods $(P<0.01)$ and in the frequency of exclusion of foods $(P<0.01)$ between both groups. About $80 \%$ of patients with IBS excluded some food from the diet and the total amount of troublesome foods varied from 7 to 21 for those carriers of IBS. 
TABLE 4. Comparison of troublesome foods for controls and cases.

\begin{tabular}{|c|c|c|c|}
\hline \multirow{2}{*}{ Foods } & \multicolumn{2}{|c|}{ Research group } & \multirow{2}{*}{$P$ value } \\
\hline & Controls n (\%) & Cases n (\%) & \\
\hline Apple & $1(2.8)$ & $8(23.5)$ & $0.010^{\mathrm{a}}$ \\
\hline Pear & $1(2.8)$ & $6(17.6)$ & $0.038^{\mathrm{a}}$ \\
\hline Peach & $0(0.0)$ & $5(14.7)$ & $0.017^{\mathrm{a}}$ \\
\hline Mango & $0(0.0)$ & $13(38.2)$ & $<0.01^{\mathrm{a}}$ \\
\hline Cherry & $0(0.0)$ & $0(0.0)$ & - \\
\hline Nectarine & $0(0.0)$ & $1(2.9)$ & $0.300^{\mathrm{a}}$ \\
\hline Watermelon & $3(8.3)$ & $12(35.2)$ & $0.006^{\mathrm{a}}$ \\
\hline Honey & $0(0.0)$ & $1(2.9)$ & $0.300^{\mathrm{a}}$ \\
\hline Natural juice & $2(5.6)$ & $9(26.5)$ & $0.016^{\mathrm{a}}$ \\
\hline Artichoke & $0(0.0)$ & $0(0.0)$ & - \\
\hline Beet & $0(0.0)$ & $6(17.6)$ & $0.008^{\mathrm{a}}$ \\
\hline Broccoli & $3(8.3)$ & $14(41.2)$ & $0.001^{\mathrm{a}}$ \\
\hline Cabbage & $8(22.2)$ & $21(61.8)$ & $0.001^{\mathrm{a}}$ \\
\hline Okra & $1(2.8)$ & $6(17.6)$ & $0.038^{\mathrm{a}}$ \\
\hline Garlic & $1(2.8)$ & $6(17.6)$ & $0.038^{\mathrm{a}}$ \\
\hline Onion & $0(0.0)$ & $9(26.5)$ & $0.001^{\mathrm{a}}$ \\
\hline Cauliflower & $4(11.1)$ & $11(32.4)$ & $0.030^{\mathrm{a}}$ \\
\hline Industrial tomato sauce & $7(19.4)$ & $17(50.0)$ & $0.007^{\mathrm{a}}$ \\
\hline Pea & $0(0.0)$ & $4(11.8)$ & $0.034^{a}$ \\
\hline Chickpeas & $4(11.1)$ & $8(23.5)$ & $0.168^{\mathrm{a}}$ \\
\hline Lentils & $1(2.8)$ & $5(14.7)$ & $0.075^{\mathrm{a}}$ \\
\hline Beans & $12(33.3)$ & $26(76.5)$ & $<0.01^{\mathrm{a}}$ \\
\hline Milk & $9(25.0)$ & $28(82.4)$ & $<0.01^{\mathrm{a}}$ \\
\hline Ice cream & $3(8.3)$ & $19(55.9)$ & $<0.01^{\mathrm{a}}$ \\
\hline Yogurt & $5(13.9)$ & $18(52.9)$ & $<0.01^{\mathrm{a}}$ \\
\hline Condensed milk & $0(0.0)$ & $19(52.9)$ & $<0.01^{\mathrm{a}}$ \\
\hline Fresh cheeses & $1(2.8)$ & $20(58.8)$ & $<0.01^{\mathrm{a}}$ \\
\hline Wheat- or rye-based foods & $5(13.9)$ & $19(55.9)$ & $<0.01^{\mathrm{a}}$ \\
\hline White bread & $7(19.4)$ & $14(41.2)$ & $0.047^{\mathrm{a}}$ \\
\hline Whole wheat bread & $2(5.6)$ & $6(17.6)$ & $0.112^{\mathrm{a}}$ \\
\hline Pasta & $2(5.6)$ & $13(38.2)$ & $0.001^{\mathrm{a}}$ \\
\hline Rice & $1(2.8)$ & $8(23.5)$ & $0.01^{\mathrm{a}}$ \\
\hline Chocolate & $2(5.6)$ & $19(55.9)$ & $<0.01^{\mathrm{a}}$ \\
\hline Fried foods & $6(16.7)$ & $24(70.6)$ & $<0.01^{\mathrm{a}}$ \\
\hline Pizza & $3(8.3)$ & $19(55.9)$ & $<0.01^{\mathrm{a}}$ \\
\hline Pies and pastries & $1(2.8)$ & $18(52.9)$ & $<0.01^{\mathrm{a}}$ \\
\hline Coffee & $1(2.8)$ & $13(38.2)$ & $<0.01^{\mathrm{a}}$ \\
\hline Alcoholic beverage & $3(8.3)$ & $7(20.6)$ & $0.143^{\mathrm{a}}$ \\
\hline Beef & $4(11.1)$ & $15(44.1)$ & $0.002^{\mathrm{a}}$ \\
\hline Pork & $1(2.8)$ & $12(35.3)$ & $<0.01^{\mathrm{a}}$ \\
\hline Chicken & $0(0.0)$ & $5(14.7)$ & $0.017^{a}$ \\
\hline Fish & $0(0.0)$ & $2(5.9)$ & $0.140^{\mathrm{a}}$ \\
\hline $\begin{array}{l}\text { Total amount of } \\
\text { troublesome foods }\end{array}$ & $3 \pm 3$ & $14 \pm 7$ & $<0.01^{\mathrm{b}}$ \\
\hline $\begin{array}{l}\text { Food exclusion from the } \\
\text { diet }\end{array}$ & 25.0 & 79.4 & $<0.01^{a}$ \\
\hline
\end{tabular}

Values are presented as $\%$ or mean $\pm \mathrm{SD}$ (range). ${ }^{\mathrm{a} C h i}$-square test. 'btudent's t-test.

\section{Quality of life}

Quality of life was worse in case group than in the control group. There was worse quality of life for the domains dysphoria, interference with activity, body image, health concerns, food prevention, social reaction, sexuality, relationships $(P<0.01)$, and in the overall quality of life $(P<0.01)$ for carriers of IBS, compared with the control group (TABLE 5).

TABLE 5. Comparison of overall quality of life and of each subdomain of the questionnaire of quality of life for IBS carriers, in groups and controls.

\begin{tabular}{lccc}
\hline \multirow{2}{*}{ Domains } & \multicolumn{2}{c}{ Research group } & $\boldsymbol{P}$ \\
\cline { 2 - 3 } & Controls & Cases & value $^{\mathrm{a}}$ \\
\hline Dysphoria & $81.6 \pm 23.7$ & $67.0 \pm 25.2$ & $<0.01$ \\
Interference with activity & $71.3 \pm 29.9$ & $47.2 \pm 24.3$ & $<0.01$ \\
Body image & $70.9 \pm 29.9$ & $50.0 \pm 25.2$ & $<0.01$ \\
Health concerns & $66.6 \pm 32.0$ & $45.1 \pm 25.7$ & $<0.01$ \\
Food prevention & $67.1 \pm 31.3$ & $44.8 \pm 28.0$ & $<0.01$ \\
Social reaction & $83.7 \pm 41.0$ & $74.8 \pm 56.5$ & $<0.01$ \\
Sexuality & $81.2 \pm 24.4$ & $64.3 \pm 33.7$ & $<0.01$ \\
Relationships & $88.0 \pm 21.6$ & $77.2 \pm 26.9$ & 0.001 \\
General score of quality of life & $76.4 \pm 24.1$ & $58.7 \pm 21.7$ & $<0.01$ \\
\hline
\end{tabular}

Values are presented as mean $\pm \mathrm{SD}$ (range). ${ }^{a}$ Mann-Whitney test.

\section{DISCUSSION}

In our study we investigated the profile of body adiposity, life habits, self-reporting of troublesome foods, and the quality of life of women with IBS in comparison with a healthy control group. The main findings showed that IBS patients featured more general, abdominal, and gluteofemoral adiposity; higher frequency of comorbidities and use of antidiarrheals; less consumption of alcoholic beverages; higher frequency of self-reporting of troublesome foods and food exclusion from the diet; and worse quality of life when compared with controls.

We found positive association between IBS and increased volume of android fat, according to waist circumference, and gynoid, according to hip circumference, and general fat according to BMI. In literature there are studies with controversial results concerning the association of BMI with gastrointestinal symptoms $\mathrm{s}^{(8-12,14,15,17,33,34)}$. In prospective studies, Aasbrenn $\mathrm{M}$ et al. ${ }^{(14)}$ and Sadik $\mathbf{R}^{(35)}$ demonstrated that visceral adiposity and waist circumference are associated with a significant increase in the risk of IBS, in addition to the association between increased severity of IBS symptoms and increase in BMI. A diet poor in fiber, and rich in saturated fat and fermentable carbohydrates may contribute to IBS symptoms in obese individuals ${ }^{(8)}$. Moreover, high BMI is related to increased colon transit and the consequent increase in gastrointestinal symptoms. In patients with overweight, colon and rectosigmoid transit were faster compared with eutrophic patients, and symptoms of pain/discomfort and swelling are also associated with abnormalities of the colon transit in obese patients with IBS ${ }^{(35)}$. On the other hand, a study conducted by Van Oijen et al. ${ }^{(36)}$ with 1023 individuals reported that BMI alone does not predict the occurrence of gastrointestinal disorders and symptoms such as abdominal pain, diarrhea, and constipation. Authors of a recent study on a large sample of patients with IBS 
and control individuals demonstrated that obesity is as much often found in IBS as in the general population ${ }^{(37)}$. The fact the control group has a BMI $<30 \mathrm{~kg} / \mathrm{m}^{2}$ as inclusion criterion may have favored the findings of higher adiposity in case individuals, since the population of Brazilian adult women features an obesity prevalence of $18.7 \%{ }^{(38)}$.

In our study, we found a statistically significant difference in the presence of comorbidities associated with IBS. IBS is commonly manifested with other chronic painful disorders, such as dyspepsia, fibromyalgia, chronic fatigue syndrome, and temporomandibular joint dysfunctions ${ }^{(25,39)}$. A systematic-review study conducted by Whitehead et al. ${ }^{(40)}$ found association of IBS with other nongastrointestinal disorders, such as fibromyalgia (49\%), chronic fatigue syndrome $(51 \%)$, temporomandibular joint dysfunction $(64 \%)$, and chronic pelvic pain $(50 \%)$, suggesting that each disorder is the manifestation of varied combinations of physiological and psychological factors that interact. The use of antidiarrheals for those carriers of IBS was significantly higher compared with healthy individuals. An alternative as a second-line treatment for gastrointestinal symptoms of IBS is using laxatives and antidiarrheals ${ }^{(25)}$. The use of laxatives can promote constipation relief with improvement in quality of life, being well tolerated in adults and children, and it may contribute to change the consistency and shape of feces ${ }^{(41,42)}$.

Among the analyzed parameters regarding life habits, consumption of alcoholic beverages showed significant difference between cases and controls. Patients with IBS have intolerance to several alcoholic beverages, and generally have low consumption of such due to aggravations to gastrointestinal symptoms such as abdominal pain and diarrhea caused by the change of intestinal permeability and motility ${ }^{(7,22)}$. Advice on healthy eating and lifestyle are recommended as first-line approach in the dietary handling of IBS, and the standard recommendation is to decrease the consumption of alcoholic beverages because of its association with gastrointestinal symptoms in IBS patients ${ }^{(43)}$.

Most foods deemed troublesome in literature ${ }^{(29)}$ and investigated in our study were reported as triggers of gastrointestinal symptoms in IBS carriers when compared with the healthy control group. Food intolerance is a frequent problem with significant consequences for individuals with IBS. Many patients with IBS associate eating some foods (such as dairy products, wheat-based products, spicy and fried foods, fruits and vegetables) with the onset and development of IBS symptoms, and about $62 \%$ of individuals have diet restrictions or exclusion $^{(44,45)}$. These foods are rich in FODMAPs and IBS individuals are often intolerable to these carbohydrates ${ }^{(2,45)}$. According Mullin et al. ${ }^{(2)}$, individuals who manifest adverse reactions to foods present worse quality of life and cases of anxiety or depression associated with IBS. Diets with low levels of FODMAPs, with different proportions of proteins, fats, and carbohydrates, can improve symptoms in patients by decreasing patterns of abdominal pain and bloating, and improve quality of life in more than half of patients with $\operatorname{IBS}^{(2,45-47)}$.

In our study we noted worse overall quality of life in all studied domains in IBS patients compared with healthy individuals, being food prevention and health concerns the most affected subdomains in patients with the syndrome. IBS causes reduction of quality of life with the same degree of commitment as diabetes, congestive heart failure, kidney failure, and liver cirrhosis ${ }^{(48)}$. The QOL of patients with IBS was influenced by extraintestinal symptoms, such as sexuality, mood, and anxiety, in addition to the decrease in QOL concerning energy/fatigue, limitations to perform their daily activities at work, pain, overall perception of health, inability to follow an unrestricted diet, and worsening in relationships, aggravating the functional status and well-being of patients ${ }^{(4,49,50)}$. The fear of gastrointestinal aggravations is also a predictive of impairment of QOL, increased anxiety, and social isolation ${ }^{(5,6)}$. A clinically significant change in patients with IBS is seen from the therapeutic gain of $\geq 14$ points in the IBS-QOL ${ }^{(5)}$.

Certainly, there are limitations in our study. We conducted it in a secondary/tertiary healthcare scenario, which hinders the generalization of findings to the overall IBS population. As aforementioned, the fact the control group has a BMI $<30 \mathrm{~kg} / \mathrm{m}^{2}$ may have favored the findings of higher adiposity in case individuals. Finally, the final sample size was small, which made separate analyses with each IBS phenotype impossible.

Therefore, in our case-control study conducted on adult women, IBS was associated with body adiposity, chronic painful disorders, food restriction, lower consumption of alcoholic beverages, and worst quality of life compared with healthy individuals, thus suggesting a demand of multidisciplinary health care towards this population. Confirmation of these data in other population extracts would assist in the comprehensive understanding of the clinical nutritional profile of these individuals, and may support interventions and handling of IBS.

\section{ACKNOWLEDGEMENTS}

We thank Prof. Cristiane Kibune Nagasako and Prof. Ciro Garcia Montes for assistance with data collection. We would also like to thank National Council for Scientific and Technological Development (CNPq) and São Paulo Research Foundation FAPESP for funding the study.

\section{Authors' contribution}

Conceptualization: all authors. Methodology: Yamashita LM, Solar I, Santos LAO, Vasques ACJ. Formal analysis: Mendonça APM, Vasques ACJ. Funding acquisition: Vasques ACJ. Project administration: Vasques ACJ. Visualization: Mendonça APM, Yamashita LM, Vasques ACJ. Writing - original draft: Mendonça APM. Writing - review and editing: Yamashita LM, Vasques ACJ. Approval of final manuscript: all authors.

\section{Orcid}

Ana Paula Monteiro de Mendonça: 0000-0001-5218-3791.

Luciana Miyuki Yamashita: 0000-0002-6233-1142.

Esther Dantas Silva: 0000-0001-6323-8743.

Isabela Solar: 0000-0003-3500-1567.

Larissa Ariel Oliveira Santos: 0000-0002-3663-1942.

Ana Carolina Junqueira Vasques: 0000-0001-9222-1107. 
Mendonça APM, Yamashita LM, Silva ED, Solar I, Santos LAO, Vasques ACJ. Estado nutricional, qualidade de vida e hábitos de vida em mulheres com síndrome do intestino irritável: um estudo caso-controle. Arq Gastroenterol. 2020;57(2):114-20.

RESUMO - Contexto - A síndrome do intestino irritável é uma desordem gastrointestinal crônica e funcional que pode causar dor abdominal e alteração do hábito intestinal, afetando o estado nutricional e a qualidade de vida. Sua prevalência é alta, acomete cerca de $10 \%$ a $15 \%$ da população geral em países desenvolvidos, sendo mais prevalente em mulheres do que em homens na proporção 2:1. Objetivo - O objetivo deste estudo foi comparar o perfil de adiposidade corporal, os hábitos de vida e a qualidade de vida de indivíduos portadores da síndrome do intestino irritável com um grupo controle saudável. Métodos - Estudo caso-controle com 70 mulheres, 34 com a síndrome do intestino irritável e 36 saudáveis. Foi aplicado o Irritable Bowel Syndrome Quality of Life Questionnaire para avaliação da qualidade de vida. A adiposidade corporal foi avaliada a partir do índice de massa corporal, circunferência da cintura e relação cintura-quadril. Foi investigado o auto-relato de sintomas gastrointestinais de alimentos considerados problemáticos para portadores da síndrome do intestino irritável e a presença de comorbidades típicas. A análise do estilo de vida incluiu a prática de atividade física, alcoolismo, tabagismo, sonolência diurna e exclusão de alimentos. Para análise estatística foi utilizado o programa IBM SPSS, com o nível de significância de $5 \%$. Resultados - Houve maior acúmulo de adiposidade central e periférica no grupo caso em comparação ao grupo controle $(P<0,05)$. Os casos apresentaram maior chance de desenvolver comorbidades associadas à síndrome do intestino irritável $(P<0,05)$. Cerca de $80 \%$ dos pacientes com a síndrome do intestino irritável excluíram algum alimento da dieta $(P<0,01)$ e o total de alimentos problemáticos pode variar de 7 a 21 alimentos $(P<0,01)$. Grupo caso apresentou pior qualidade de vida para o escore geral e para todos os domínios avaliados $(P<0,05)$. Conclusão - Em comparação aos controles, as mulheres portadoras da síndrome do intestino irritável apresentaram maior adiposidade corporal, maior frequência de comorbidades, maior restrição ao consumo de alimentos considerados problemáticos e pior qualidade de vida.

DESCRITORES - Síndrome do intestino irritável. Adiposidade. Estilo de vida. Qualidade de vida.

\section{REFERENCES}

1. Ford AC, Lacy BE, Talley NJ. Irritable bowel syndrome. N Engl J Med. 2017;376:2566-78

2. Mullin GE, Shepherd SJ, Chander BR, Ireton-Jones C, Matarese LE. Irritable bowel syndrome: contemporary nutrition management strategies. J Parenter Enteral Nutr. 2014;38:781-99

3. Mizukami T, Sugimoto S, Masaoka T, Suzuki H, Kanai T. Colonic dysmotility and morphological abnormality frequently detected in Japanese patients with irritable bowel syndrome. Intest Res. 2017;15:236-43.

4. Gralnek IM, Hays RD, Kilbourne A, Naliboff B, Mayer EA. The impact of irritable bowel syndrome on health-related quality of life. Gastroenterologia. 2000;119:654-60.

5. Enck P, Aziz Q, Barbara G, Farmer AD, Fukudo S, Mayer EA, et al. Irritable bowel syndrome. Nat Rev Dis Primers. 2016;2:16014

6. Lackner JM, Gudleski GD, Ma CX, Dewanwala A, Naliboff B. Representing the IBSOS Outcome Study Research Group. Fear of GI symptoms has an important impact on quality of life in patients with moderate-to-severe IBS. Am J Gastroenterol. 2014;109:1815-23.

7. El-Salhy M. Recent developments in the pathophysiology of irritable bowel syndrome. World J Gastroenterol. 2015;21:7621-36.

8. Pickett-Blakely O. Obesity and irritable bowel syndrome: a comprehensive review. Gastroenterol Hepatol. 2014;10:411-6.

9. Kibune Nagasako C, Garcia Montes C, Silva Lorena SL, Mesquita MA. Irritable bowel syndrome subtypes: Clinical and psychological features, body mass index and comorbidities. Rev Esp Enferm Dig. 2016;108:59-64.

10. Delgado-Aros S, Locke GR, Camilleri M, Talley NJ, Fett S, Zinsmeister AR, et al. Obesity is associated with increased risk of gastrointestinal symptoms: a population-based study. Am J Gastroenterol. 2004;99:1801-6.

11. Sadik R, Abrahamsson H, Ung KA, Stotzer PO. Accelerated regional bowel transit and overweight shown in idiopathic bile acid malabsorption. Am J Gastroenterol. 2004;99:711-8.

12. Ho W, Spiegel BM. The relationship between obesity and functional gastrointestinal disorders: causation, association, or neither? Gastroenterol Hepatol. 2008;4:572-8.

13. Clements RH, Gonzalez QH, Foster A, Richards WO, McDowell J, Bondora A, et al. Gastrointestinal symptoms are more intense in morbidly obese patients and are improved with laparoscopic Roux-en-Y gastric bypass. Obes Surg. 2003;13:610-4

14. Aasbrenn M, Lydersen S, Farup PG. A Conservative Weight Loss Intervention Relieves Bowel Symptoms in Morbidly Obese Subjects with Irritable Bowel Syndrome: A Prospective Cohort Study. J Obes. 2018;2018:3732753.

15. Lee CG, Lee JK, Kang YS, Shin S, Kim JH, Lim YJ, et al. Visceral abdominal obesity is associated with an increased risk of irritable bowel syndrome. Am J Gastroenterol. 2015;110:310-9.

16. Talley NJ, Howell S, Poulton R. Obesity and chronic gastrointestinal tract symptoms in young adults: a birth cohort study. Am J Gastroenterol. 2004;99:1807-14.
17. Kubo M, Fujiwara Y, Shiba M, Kohata Y, Yamagami H, Tanigawa T, et al. Differences between risk factors among irritable bowel syndrome subtypes in Japanese adults. Neurogastroenterol Motil. 2011;23:249-54.

18. Levy RL, Linde JA, Feld KA, Crowell MD, Jeffery RW. The association of gastrointestinal symptoms with weight, diet, and exercise in weight-loss program participants. Clin Gastroenterol Hepatol. 2005;3:992-6.

19. Heizer WD, Southern S, McGovern S. The role of diet in symptoms of irritable bowel syndrome in adults: a narrative review. J Am Diet Assoc. 2009;109:1204-14.

20. Hayes P, Corish C, O'mahony E, Quigley EMM. A dietary survey of patients with irritable bowel syndrome. J Hum Nutr Diet. 2014;27:36-47.

21. Böhn L, Störsrud S, Törnblom H, Bengtsson U, Simrén M. Self-reported food-related gastrointestinal symptoms in IBS are common and associated with more severe symptoms and reduced quality of life. Am J Gastroenterol. 2013;108: 634-41.

22. Reding KW, Cain KC, Jarrett ME, Eugenio MD, Heitkemper MM. Relationship between patterns of alcohol consumption and gastrointestinal symptoms among patients with irritable bowel syndrome. Am J Gastroenterol. 2013;108:270-6.

23. Sirri L, Grandi S, Tossani E. Smoking in irritable bowel syndrome: a systematic review. J Dual Diagn. 2017;13:184-200.

24. Guo YB, Zhuang KM, Kuang L, Zhan Q, Wang XF, Liu SD. Association between Diet and Lifestyle Habits and Irritable Bowel Syndrome: A Case-Control Study. Gut Liver. 2014;9:649-56.

25. Irritable Bowel Syndrome (IBS). World Gastroenterology Organization web site. http://www.worldgastroenterology.org/guidelines/global-guidelines/irritable-bowel-syndrome-ibs. Updated September 2015. Accessed August 30, 2018.

26. Matsudo S, Araújo T, Matsudo V, Andrade D, Andrade E, Oliveira L, et al. International Physical Activity Questionnaire (IPAQ): Study of validity and reliability in Brazil. Rev Bras ativ fis saúde 2001;6:5-18.

27. Ford ES, Kohl III HW, Mokdad AH, Ajani UA. Sedentary behavior, physical activity, and the metabolic syndrome among U.S. adults. Obes Res. 2005;13:608-14.

28. Bertolazi AN, Fagondes SC, Hoff LS, Pedro VD, Menna Barreto SS, Johns MW. Validation of the Epworth Sleepiness Scale in the brazilian portuguese language. Sleep. 2008;31:347-47.

29. Böhn L, Störsrud S, Törnblom H, Bengtsson U, Simrén M. Self-reported food-related gastrointestinal symptoms in IBS are common and associated with more severe symptoms and reduced quality of life. Am J Gastroenterol. 2013; 108:634-41.

30. Patrick DL, Drossman DA, Frederick IO, Di Cesare J, Puder KL. Quality of life in persons with irritable bowel syndrome: development and validation of a new measure. Dig Dis Sci. 1998;43:400-11.

31. World Health Organization. Physical status: the use and interpretation of anthropometry. Geneva: WHO; 1995.

32. Cuppari L. Guideline of nutrition: clinical nutrition of adults. 2 ed. Barueri: Manole; 2005. 
33. Talley NJ, Quan C, Jones MP, Horowitz M. Association of upper and lower gastrointestinal tract symptoms with body mass index in an Australian cohort. Neurogastroenterol Motil. 2004;16:413-9.

34. Talley NJ, Howell S, Poulton R. Obesity and chronic gastrointestinal tract symptoms in young adults: a birth cohort study. Am J Gastroenterol. 2004:99:1807-14.

35. Sadik R, Björnsson E, Simrén M. The relationship between symptoms, body mass index, gastrointestinal transit and stool frequency in patients with irritable bowel syndrome. Eur J Gastroenterol Hepatol. 2010;22:102-8.

36. Van Oijen MG, Josemanders DF, Laheij RJ, Van Rossum LG, Tan AC, Jansen JB. Gastrointestinal disorders and symptoms: does body mass index matter? Neth J Med. 2006;64:45-9.

37. Rusu F. Obesity and irritable bowel syndrome: coincidence or association? J Gastrointestin Liver Dis. 2018;27:205.

38. Brazil. Ministério da Saúde. Vigitel Brazil 2017: surveillance of risk and protective factors for chronic diseases by telephone survey: estimates of Frequency and sociodemographic distribution of risk and protective factors for chronic diseases in the capitals of the 26 Brazilian states and the Federal District in 2017. Available from: http://bvsms.saude.gov.br/bvs/publicacoes/vigitel_brasil_2017_vigilancia_fatores_risco.pdf.

39. Kim SE, Chang L. Overlap between functional GI disorders and other functional syndromes: what are the underlying mechanisms? Neurogastroenterol Motil. 2012;24:895-913.

40. Whitehead WE, Palsson O, Jones KR. Systematic review of the comorbidity of irritable bowel syndrome with other disorders: what are the causes and implications? Gastroenterology. 2002;122:1140-56.

41. Paré P, Fedorak RN. Systematic review of stimulant and nonstimulant laxatives for the treatment of functional constipation. Can J Gastroenterol Hepatol. 2014;28:549-57.
42. Dinning PG, Hunt L, Lubowski DZ, Kalantar JS, Cook IJ, Jones MP. The impact of laxative use upon symptoms in patients with proven slow transit constipation. BMC Gastroenterol. 2011;11:121.

43. Cozma-Petruţ A, Loghin F, Miere D, Dumitraşcu DL. Diet in irritable bowel syndrome: What to recommend, not what to forbid to patients! World J Gastroenterol. 2017;23:3771-83.

44. Monsbakken KW, Vandvik PO, Farup PG. Perceived food intolerance in subjects with irritable bowel syndrome-etiology, prevalence and consequences. 2006;60:667-72.

45. Mazzawi T, El-Salhy M. Effect of diet and individual dietary guidance on gastrointestinal endocrine cells in patients with irritable bowel syndrome (Review) Int J Mol Med. 2017;40:943-52.

46. Dolan R, Chey WD, Eswaran S. The role of diet in the management of irritable bowel syndrome: a focus on FODMAPs. Expert Rev Gastroenterol Hepatol. 2018;12:607-15.

47. Halmos EP, Power VA, Shepherd SJ, Gibson PR, Muir JG. A diet low in FODMAPs reduces symptoms of irritable bowel syndrome. Gastroenterology. 2014;146:67-75.

48. El-Salhy M. Irritable bowel syndrome: diagnosis and pathogenesis. World J Gastroenterol. 2012;18:5151-63.

49. Spiegel BM, Gralnek IM, Bolus R, Chang L, Dulai GS, Mayer EA, et al. Clinica determinants of health-related quality of life in patients with irritable bowel syndrome. Arch Intern Med 2004;164:1773-80.

50. Eswaran S, Chey WD, Jackson K, Pillai S, Chey SW, Han-Markey T. A diet low in fermentable oligo-, di-, and monosaccharides and polyols improves quality of life and reduces activity impairment in patients with irritable bowel syndrome and diarrhea. Clin Gastroenterol Hepatol. 2017;15:1890-9. 